\title{
In Vitro Evaluation of Cholesterol-Reducing Ability of Chitosan from Mangrove Crab (Scylla serrata) Shell Solid Dispersion using PVP K-30 as a Carrier
}

\section{Uji In Vitro Penurunan Kadar Kolesterol Sistem Dispersi Padat Kitosan dari Cangkang Kepiting Bakau (Scylla serrata) Menggunakan PVP K-30 Sebagai Pembawa}

\author{
Hilya Nur Imtihani", Silfiana Nisa Permatasari, Rahmad Aji Prasetya
}

Program Studi DIII Farmasi, Akademi Farmasi Surabaya, Surabaya, Indonesia. *E-mail: hilya.imtihani@gmail.com

\author{
Article Info: \\ Received: 27 August 2021 \\ in revised form: 2 September 2021 \\ Accepted: 9 September 2021 \\ Available Online: 2 October 2021 \\ Keywords: \\ Mangrove crab shell \\ Chitosan \\ Decreasing cholesterol \\ Solid dispersion \\ In vitro assay \\ Corresponding Author: \\ Hilya Nur Imtihani \\ Program Studi DIII Farmasi \\ Akademi Farmasi Surabaya \\ Surabaya \\ Indonesia \\ email: hilya.imtihani@gmail.com
}

\begin{abstract}
Background: Chitosan is a compound that can be synthesized from nature which can reduce the total serum cholesterol levels between $5.8-42.6 \%$ and decrease LDL (Low-Density Lipoprotein) between 15.1-35.1\%. One of the natural resources containing chitosan derivative compounds is the shell of mud crab. Chitosan is insoluble in water but soluble in acidic solutions such as acetic acid. With such chitosan solubility, it is necessary to increase the solubility by making a solid dispersion system so that drug absorption can be faster. Objectives: The aims of this study is to determine the potential of chitosan solid dispersion system for reducing cholesterol. Material and Methods: The reduction of cholesterol levels was carried out by in vitro tests using UV-Vis spectrophotometer at a wavelength of $405 \mathrm{~nm}$ with Lieberman-Burchad reagent. The positive control used was simvastatin. There are 4 formulas, namely SD1, PM1, SD2, and PM2. This solid dispersion system uses polyvinyl pyrrolidone K-30 (PVP K-30) as carrier. Results: The characterization of chitosan has fulfilled all the characterization requirements that is organoleptic (shape and color) was creamy white, moisture content was $2.15 \%$, ash content was $1.14 \%$, ninhydrin test was positive purple, and deacetylation degree was $70.57 \%$. The results of in vitro evaluation were obtained a dark green solution. The reducing percentage in cholesterol levels are SD1: 18.44\%; PM1 : 18.11\%; SD2 : $29.57 \%$; and PM2 :12.01\%. Simvastatin as a positive control has a percentage reduction in cholesterol levels of $30.07 \%$. Conclusion: Chitosan has an activity as anticholesterol agent. SD2 (Solid Dispersion Chitosan: PVP K-30 = 1:2) has the higher percentage than other formulas for reducing cholesterol level comparable with the positive control.
\end{abstract}

How to cite (APA $6^{\text {th }}$ Style):

Imtihani. H.N., Permatasari. S. N., Prasetya. R. A. (2021). In Vitro Evaluation of Cholesterol-Reducing Ability of Chitosan from Mangrove Crab (Scylla serrata) Shell Solid Dispersion using PVP K-30 as a Carrier. Jurnal Farmasi Galenika :Galenika Journal of Pharmacy (e-Journal), 7(2), 99-109. doi:10.22487/j24428744.2021.v7.i2.15597 


\begin{abstract}
ABSTRAK
Latar Belakang: Kitosan merupakan senyawa yang dapat disintesis dari alam yang dapat menurunkan kadar kolesterol total serum antara 5,8-42,6\% dan menurunkan LDL (Low-Density Lipoprotein) antara 15,1-35,1\%. Salah satu sumber daya alam yang mengandung senyawa turunan kitosan adalah cangkang kepiting bakau. Kitosan sendiri tidak larut dalam air tetapi larut dalam larutan asam seperti asam asetat. Dengan kelarutan kitosan yang demikian maka perlu ditingkatkan salah satunya dengan membuat sistem dispersi padat agar penyerapan obat dapat lebih cepat. Tujuan: Penelitian ini bertujuan untuk mengetahui potensi sistem dispersi padat kitosan dalam menurunkan kolesterol. Bahan dan Metode: Penurunan kadar kolesterol pada penelitian ini dilakukan dengan uji in-vitro menggunakan spektrofotometer UV-Vis pada panjang gelombang $405 \mathrm{~nm}$ menggunakan pereaksi Lieberman-Burchad. Kontrol positif yang digunakan adalah simvastatin. Ada 4 formula yang dibuat yaitu SD1, PM1, SD2, dan PM2. Sistem dispersi padat ini menggunakan PVP K-30 sebagai pembawa. Hasil: Hasil karakterisasi kitosan telah memenuhi semua persyaratan yaitu organoleptik (bentuk dan warna) putih krem, kadar air: 2,15\%, kadar abu: 1,14\%, uji ninhidrin positif ungu, dan derajat deasetilasi : 70,57\%. Hasil evaluasi in vitro diperoleh larutan berwarna hijau tua. Persentase penurunan kadar kolesterol adalah SD1: 18,44\%; PM1: 18,11\%; SD2: 29,57\%; dan PM2: 12,01\%. Simvastatin sebagai kontrol positif memiliki persentase penurunan kadar kolesterol sebesar 30,07\%. Kesimpulan: Kitosan memiliki aktivitas sebagai antikolesterol. Formula SD2 (Solid Dispersion Kitosan: PVP K-30 = 1:2) memiliki presentase terbesar dari semua formula dalam menurunkan kadar kolesterol dan mendekati kontrol positif.
\end{abstract}

Kata kunci: Cangkang kepiting bakau; Kitosan; Penurunan kolesterol; Dispersi padat; Uji in vitro.

\title{
INTRODUCTION
}

Along with the modernization of life, humans are fast-paced in their activities. This causes some people tend to consume fast food (fast food) which contains a lot of fat so that it can increase cholesterol levels in the blood or hypercholesterolemia (Puspitasari, 2014).

Chitosan is a compound that can be synthesized from nature which can reduce total serum cholesterol levels between 5.8-42.6\% and decrease LDL (Low-Density Lipoprotein) between 15.1-35.1\% (Ylitalo et al., 2002). There are two basic mechanisms of chitosan in binding fat, which involve attraction such as magnetic poles which have two opposite charges and a charge neutralization mechanism, namely, chitosan covers the active site of fat and protects it from attack and decomposition of lipid enzymes (Pagala, 2011).

One of the natural resources containing chitosan derivative compounds is crab. Indonesia is the largest crab exporting country for the international market with a fairly fantastic value so that it produces a lot of crab shell waste. Crab shells contain chitin $(18.70 \%$ - 32.20\%) which can be converted into chitosan (Maidin Nasir Alfian, 2017). The synthesis of chitosan from mangrove crab (Scylla serrata) shells was carried out in three stages, namely deproteination, demineralization, and deacetylation. The characterization of chitosan carried out included tests of water content, ash content, degree of deacetylation, yield, ninhydrin, and organoleptic (Anas, Ajwar, 2017; Rasio et al., 2017).

Chitosan is insoluble in the air but soluble in acidic solutions such as acetic acid (Taufan et al., 2010). With such chitosan solubility, it is necessary to increase it by making a solid dispersion system so that drug absorption can be faster. The use of a solid dispersion system also has many advantages including, 
reduced particle size (reduced), increasing the wettability of the drug so that it is more easily dissolved (Trianggani \& Sulistiyaningsih, 2018). Solid dispersion is a mixture of one or more active substances which are dispersed into an inert carrier in the solid-state. The method of making solid dispersions in this study is solvent evaporation because it has the best advantage, namely, it can prevent the decomposition of drug ingredients (Trianggani \& Sulistiyaningsih, 2018).

The selection and comparison of the carrier material also determine the success in increasing the dissolution rate of the drug. According to research, it has been proven that the manufacture of solid dispersions with polyvinyl pyrrolidone K-30 (PVP K-30) as a carrier can increase the dissolution rate of the drug (Umar et al., 2014). The ratio of active ingredients: carrier used in this study was chitosan: PVP $\mathrm{K}-30=1: 1$ and 1:2 (11). The solid dispersion will be compared with a physical mixture with the same ratio.

The reduction of cholesterol levels in this study was carried out by in vitro tests. In vitro test was carried out by observing the decrease in cholesterol levels when added to the amount of chitosan which was seen using a UV-Vis spectrophotometer at a wavelength of 200-800 nm ( $\underline{\mathrm{Adu}}$ et al., 2019).

This study aims to see the ability of solid dispersion of crab shell chitosan in lowering cholesterol levels. This needs to be done for the development of chitosan, which is the second most abundant product that can be synthesized from natural ingredients whose utilization is still not too widespread as an active pharmaceutical ingredient, especially anticholesterol.

\section{MATERIAL AND METHODS}

\section{Materials}

The material used in this research are cholesterol powder (analytical grade) that purchased from Sigma Aldrich, chloroform (technical grade) that purchased from Merck, Acetic anhydride (analytical grade) that purchased from Merck, $\mathrm{H}_{2} \mathrm{SO}_{4}$ (analytical grade) that purchased from Merck, chitosan from mangrove crab (Scylla serrata) shells, PVP K-30 (technical grade), and pristine simvastatin that given by Hexpharm Jaya company.

\section{Methods}

\section{Chitosan Characterization}

Organoleptic test

Organoleptic test of chitosan was included evaluation of the shape and color of the chitosan. Typically, chitosan shows flaky powders and is light brown to white (Nasional, 2013).

Moisture content test

The sample of chitosan was weighed as much as 0.5 grams. Then heated using an oven at $105^{\circ} \mathrm{C}$ for 1 hour. After that, it was cooled using a desiccator for 3 hours. Weighed the results of chitosan that has been in the oven. It was alculated using the formula (Zahiruddin et al., 2008): 


$$
\% \text { moisture content }=\frac{(a-b)}{c} \times 100 \%
$$

$\mathrm{a}=$ weight of container + wet sample (grams)

$\mathrm{b}=$ weight of container + dry sample (grams)

$\mathrm{c}=$ weight of wet sample

\section{Ash content test}

Carefully weigh 2-3 g of the sample into a porcelain (or platinum) dish of known weight, for the liquid sample, evaporate over a water bath to dry. Charcoal over a burner flame, then ash in an electric furnace at a maximum temperature of $550^{\circ} \mathrm{C}$ until complete ashing (occasionally opening the furnace door slightly to allow oxygen to enter). Cool in a desiccator, then weigh it until obtained the constant weight (SNI 01-2891-1992).

$$
\% \text { ash content }=\frac{w 1-w 2}{w(g)} X 100 \%
$$

$\mathrm{w}=$ Sample weight $(\mathrm{g})$

$\mathrm{w} 1=$ Weight of sample + cup after ashing $(\mathrm{g})$

$\mathrm{w} 2$ = Weight of empty cup (g)

Ninhydrin test

The ninhydrin test was used to show the presence or absence of an amine group in chitosan. The presence of amine groups in the chitosan sample was indicated by color change into purple (Ylitalo et al., 2002) Deacetylation degree test

The degree of deacetylation of chitosan was determined by several factors, namely the concentration of $\mathrm{NaOH}$ used, the temperature and the duration of the deacetylation process. The standard percent degree of deacetylation is $70 \%$ (Dompeipen et al., 2016). The degree of deacetylation of chitosan was determined by FTIR spectroscopy and its spectrum was evaluated in the frequency range of 1000-4000 $\mathrm{cm}-1$. The DD of chitosan will be calculated using the following equation (Heidari et al., 2018):

$$
\text { Deacetylation Degree }(D D)=97,67-\left(26,486 \times\left(\frac{A_{1655}}{A_{3450}}\right)\right)
$$

\section{Solid Dispersion Preparation Method}

The Solvent Evaporation method is carried out by dissolving the drug substance, namely chitosan with a carrier material into an organic solvent that dissolves it which is then evaporated by drying using water bath and oven (Trianggani \& Sulistiyaningsih, 2018). In this study, chitosan was dissolved in 2\% acetic acid in a ratio of 1:50 then PVP K-30 dissolved with 96\% ethanol in a ratio of 1:5. Afterwards, the chitosan solution was mixed with PVP K-30 solution following the formula (Table 1) and evaporated in 
water bath at $50-60^{\circ} \mathrm{C}$ until a precipitate was formed. The resulting precipitates was then dried in the oven at $50^{\circ} \mathrm{C}$ for $2 \mathrm{~h}$ (Imtihani et al., 2021).

\section{Physical Mixture Preparation Method}

The physical mixture was made by mixing the drug substance, namely chitosan, with the carrier material, namely PVP K-30 in a ratio of 1:1 and 1:2 in a tumbler for 5 minutes.

Table 1. The Formula of Solid Dispersions (SD) and Physical Mixtures (PM).

\begin{tabular}{ccc}
\hline Formula & Chitosan (55mg) & PVP K-30 \\
\hline SD1 & 1 & 1 \\
PM1 & 1 & 1 \\
SD2 & 1 & 2 \\
PM2 & 1 & 2 \\
\hline
\end{tabular}

\section{Preparation of Stock Solution (Cholesterol 1000 ppm)}

Cholesterol powder as much as $100 \mathrm{mg}$ was dissolved in chloroform to obtain a volume of $100 \mathrm{ml}$ solution (concentration $1000 \mathrm{~g} / \mathrm{ml}$ ), and stored in the refrigerator at a temperature of $2-8^{\circ} \mathrm{C}(\underline{\mathrm{Adu}}$ et al., 2019).

\section{Determination of Maximum Wavelength}

The 1000 ppm cholesterol stock solution that has been made was taken $0.5 \mathrm{ml}$ and added chloroform ad $5 \mathrm{ml}$ to obtain a $300 \mathrm{ppm}$ cholesterol solution. $1 \mathrm{ml}$ of acetic anhydride was added, then vortexed for 30 seconds and soaked in cold water and keep in the dark for 30 minutes. $0.1 \mathrm{ml}$ of concentrated $\mathrm{H}_{2} \mathrm{SO}_{4}$ was added and homogenized with a vortex for 30 seconds and then soaked in cold water and keep in the dark for 90 minutes. Measurements were made using a UV-Vis spectrophotometer at a wavelength of 200-800 nm ( $\underline{\text { Adu }}$ et al., 2019; Kenny, 1952).

\section{Preparation of Standart Solution}

Cholesterol mother liquor with a concentration of $1000 \mathrm{ppm}$ was made in 5 concentration series, namely $0.5 ; 0.75 ; 1 ; 1.25$; and $1.5 \mathrm{ml}$ of chloroform ad $5 \mathrm{ml}$ were added, so that each solution was produced with concentrations of 100,150, 200, 250, and $300 \mathrm{ppm}$. Each solution was added $1 \mathrm{~mL}$ of acetic anhydride solution then vortexed for 30 seconds and soaked in cold water and keep in the dark for 30 minutes. Then $0.1 \mathrm{~mL}$ of concentrated $\mathrm{H}_{2} \mathrm{SO}_{4}$ was added to each solution and the solution mixture was homogenized using a vortex for 30 seconds, then soaked in cold water and keep in the dark for 90 minutes and the absorbance was measured at a maximum wavelength of $405 \mathrm{~nm}$ according to the previous measurement results (서

\section{Identification of Cholesterol}

Each sample and simvastatin (positive control) $10 \mathrm{mg}$ was added to $5 \mathrm{ml}$ of $300 \mathrm{ppm}$ cholesterol solution, the mixture was homogenized with a vortex for 30 seconds and incubated for 60 minutes at $37^{\circ} \mathrm{C}$. Then centrifuged for 5 minutes at $4000 \mathrm{rpm}$. The supernatant was taken and transferred in a closed test tube 
then it was added with $1 \mathrm{ml}$ of acetic anhydride then vortexed for 30 seconds and soaked in cold water and keep in the dark for 30 minutes, then $0.1 \mathrm{ml}$ of concentrated $\mathrm{H}_{2} \mathrm{SO}_{4}$ was added and homogenized with a vortex and soaked in cold water and keep in the dark for 90 minutes. The absorbance was measured at a maximum wavelength of $405 \mathrm{~nm}$ according to the previous measurement results ( $\underline{\mathrm{Adu}} \mathrm{et}$ al., 2019; Maidin et al., 2017). After that, the absorbance of the test was measured by the final cholesterol level compared with the standard curve with a simple linear regression formula (Lindawati \& Ningsih, 2020):

$$
\mathrm{Y}=\mathrm{bx}+\mathrm{a}
$$

$\mathrm{y}=$ Dependent variable (Absorbance)

$\mathrm{x}=$ Independent variable

$\mathrm{a}=$ Constant

$\mathrm{b}=$ Regression coefficient

then calculate the percent reduction in cholesterol levels with the formula:

$$
\mathrm{A}=\frac{\mathrm{C}-\mathrm{B}}{\mathrm{C}} * 100
$$

A: \% decrease in cholesterol levels

B: Final cholesterol level

C: Initial cholesterol level

\section{RESULTS AND DISCUSSION}

The characterization of chitosan carried out included tests of organoleptic, moisture content, ash content, ninhydrin, and degree of deacetylation. The results of the evaluation are presented in table 2.

\begin{tabular}{|c|c|c|c|}
\hline Parameter & Chitosan Characterization & Result & Interpretation \\
\hline Shape & Flakes to powder & Powder & Good \\
\hline Color & Light Brown to white & Creamy White & Good \\
\hline Moisture Content & $2-10 \%$ & $2.15 \%$ & Good \\
\hline Ash Content & $\leq 2 \%$ & $1.14 \%$ & Good \\
\hline Ninhydrin & $\begin{array}{c}(+) \\
\text { Changes to purple }\end{array}$ & $\begin{array}{c}(+) \\
\text { Changes to purple }\end{array}$ & Good \\
\hline Deacetylation Degree & $>70 \%$ & $70.57 \%$ & Good \\
\hline
\end{tabular}

Table 2. Result of Chitosan Characterization from Mangrove Crab (Scylla serrata) Shell

From the characterization of chitosan, it can be stated that chitosan has fulfilled all the characterization requirements that exist from organoleptic (shape and color) was creamy white (Yanti et al., 2018), moisture content was 2.15\% (2-10\%) (Pratiwi, 2014), ash content was $1.14 \%$ ( $\leq 2 \%$ ) (Pratiwi, 2014), ninhydrin test was positive purple( $($ Ylitalo et al., 2002), and deacetylation degree was $70.57 \%$ (>70\%)(Dompeipen et al., 2016). 
This research was preceded by measuring the maximum wavelength with a concentration of $300 \mathrm{ppm}$ in the range of $200-600 \mathrm{~nm}$. The maximun wavelength was obtained at $405 \mathrm{~nm}$ that can be seen in table 3. The peak on scanning using a UV-Vis spectrophotometer for all samples and a positive control showed a peak at a wavelength of around $300 \mathrm{~nm}$ and $400 \mathrm{~nm}$ that showed in figure 1. However, according to the reference, the maximum wavelength of cholesterol is at a $410 \mathrm{~nm}$ (Adu et al., 2019;

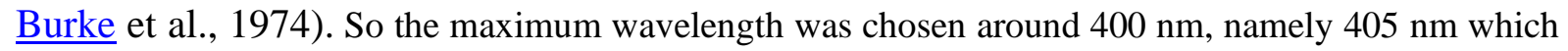
shows the highest absorbance.

Table 3. The Scanning Result of Maximun Wavelenght.

\begin{tabular}{cc}
\hline Wavelength & Absorbance \\
\hline 402 & 1.968 \\
403 & 1.969 \\
405 & 1.970 \\
406 & 1.967 \\
407 & 1.963 \\
\hline
\end{tabular}

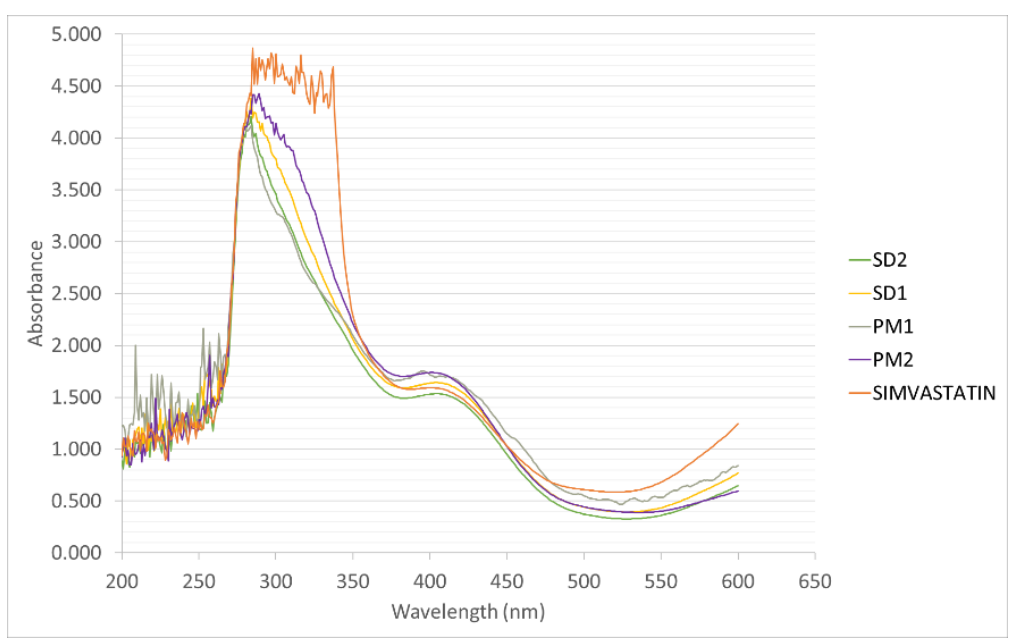

Figure 1. Cholesterol level reduction by the sample and positive control

The process is continued by making a standard cholesterol solution curve with five variations of cholesterol solution levels (Table 4). With the standard curve, it can be used to find a linear regression equation so that it can be used in the search for a level whose absorbance has been measured.

Table 4. Results of Absorbance Measurement of Standard Cholesterol Solution

\begin{tabular}{cc}
\hline Consenstration $(\mathrm{ppm})$ & Absorbance \\
\hline 100 & 0.705 \\
150 & 1.004 \\
200 & 1.290 \\
250 & 1.594 \\
300 & 1.970 \\
\hline
\end{tabular}


Based on the results of the resulting standard cholesterol solution curve, it can be seen that the curve follows Lambert-Beer's law in the form of a straight line with a value of $r^{2}=0.9971, a=0.00624, b=$ 0.0646 . So that the linear regression equation $(y=a \pm b x)$ obtained is $y=0.00624 . x+0.0646$. Figure 2 is shown the standard cholesterol solution curve.

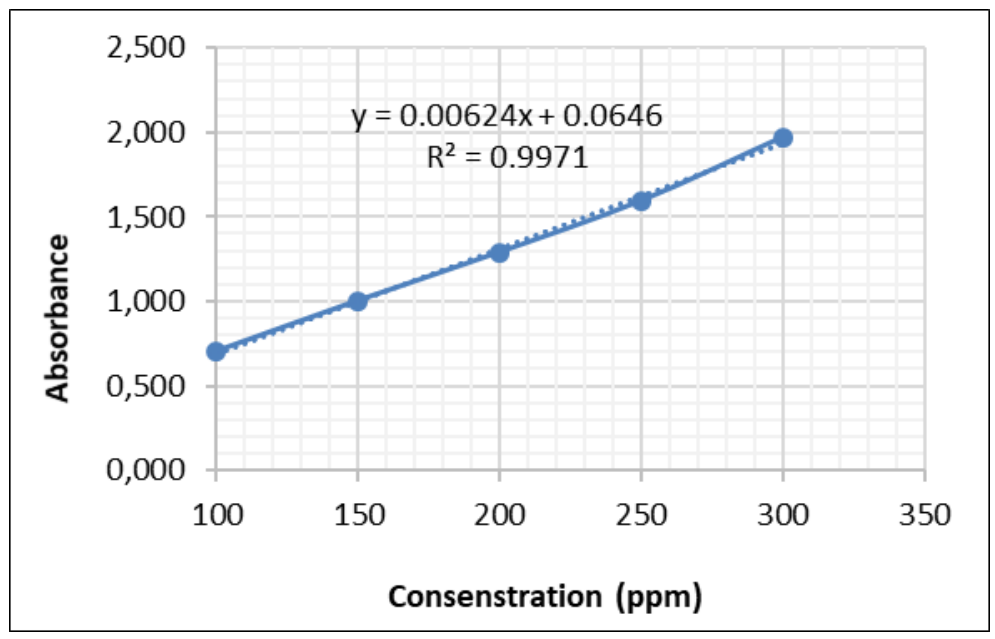

Figure 2. Standard cholesterol solution curve

The correlation coefficient value states a linear relationship between the concentration and the resulting absorption. Based on the results of $\mathrm{r}^{2}$ obtained, it is stated that the correlation coefficient gives linear results because it meets the acceptable criteria, namely 0.99 or close to 1.00 (Miller et al., 2000).

Measurement of cholesterol-lowering activity using the Lieberman-Burchard method where each sample was replicated 3 times and produced a dark green color. The result is then calculated the final cholesterol level by comparing it with the standard curve that has been obtained and the average percentage reduction in cholesterol levels from each sample is obtained (서 2017). From the results of observations and calculations that have been carried out, the result of absorbance and percent reduction in cholesterol levels by chitosan are shown in table 5 .

Table 5. The reducing percentage in cholesterol levels by the sample and positive control

\begin{tabular}{cccc}
\hline Sample & $\begin{array}{c}\text { Initial Cholesterol } \\
\text { Concentration (ppm) }\end{array}$ & $\begin{array}{c}\text { Final Cholesterol } \\
\text { Concentration }(\mathrm{ppm})\end{array}$ & $\begin{array}{c}\text { Reduction } \\
\text { Percentage (\%) }\end{array}$ \\
\hline SD1 & & 245.26 & 18.44 \\
PM1 & & 246.32 & 18.11 \\
SD2 & 300 & 211.23 & 29.56 \\
PM2 & & 263.95 & 12.01 \\
Simvastatin & & 209.78 & 30.07 \\
\hline
\end{tabular}

The result of decreasing cholesterol content between solid dispersion and physical mixture showed that the solid dispersion sample had a greater reduction than the physical mixture. SD1 was better than PM1 and SD2 was better than PM2 with the same ratio of chitosan and PVP K-30. This indicates that there is a difference in the reduction in cholesterol levels between the solid dispersion and the physical 
mixture. This is because solid dispersion is a product consisting of at least two different components, namely the hydrophobic active ingredient and the hydrophilic matrix of the active ingredient which will turn into crystalline, dissolved, or amorphous. This solid dispersion is used to accelerate the drug dissolution process (Chiou \& Riegelman, 1971). The use of this solid dispersion can help increase the absorption of drugs that are poorly soluble in water. In addition, it can also increase the speed of dissolution by changing the drug form to amorphous (Trianggani \& Sulistiyaningsih, 2018).

\section{CONCLUSION}

The solid dispersion system of mangrove crab (Scylla serrata) shell chitosan extract can reduce the cholesterol levels from the in vitro test. From the sample, the best results obtained for SD2 are $29.56 \%$ that is solid dispersion of chitosan: PVP K-30 =1:2. This value is comparable to the positive controlsimvastatin $10 \mathrm{mg}$.

\section{ACKNOWLEDGEMENT}

The authors would like to thank for financial support from LLDIKTI Wilayah VII Kementerian Pendidikan dan Kebudayaan for research grants "Penelitian Dosen Pemula" agreement No. 070/AMDSP2H/LT-MONO-PDPK/LL7/2021, 055/AKFAR-SBY/PPPM/50.02/VI/2021 tanggal 19 Juli 2021. We also thank to Akademi Farmasi Surabaya for facilities and to Hexpharm Jaya Company for the Simvastatin.

\section{CONFLICT OF INTEREST}

Authors declare that there is no conflict of interest

\section{REFERENCES}

Adu, J. K., Amengor, C. D. K., Kabiri, N., Orman, E., Abla, S., Patamia, G., \& Okrah, B. K. (2019). Validation of a Simple and Robust Liebermann - Burchard Colorimetric Method for the Assay of Cholesterol in Selected Milk Products in Ghana. 1-7. https://doi.org/https://doi.org/10.1155/2019/9045938

Anas, Ajwar, D. (2017). Pembuatan Filter Penangkap Emas ( Au ) Menggunakan Kitin dan Kitosan dari Cangkang Kepiting. IKIP Mataram, 5(2), 23-30.

Burke, R. W., Diamondstone, B. I., Velapoldi, R. A., \& Menis, O. (1974). Mechanisms of the Liebermann Burchard and Zak color reactions for cholesterol. Clinical Chemistry, 20(7), 794-801. https://doi.org/10.1093/clinchem/20.7.794

Chiou, W. L., \& Riegelman, S. (1971). Pharmaceutical applications of solid dispersion systems. Journal of Pharmaceutical Sciences, 60(9), 1281-1302. https://doi.org/10.1002/jps.2600600902

Dompeipen, E. J., Kaimudin, M., Dewa Balai Riset dan Standarisasi Industri Ambon, R. P., Cengkeh, J., \& Merah Ambon, B. (2016). Isolasi Kitin Dan Kitosan Dari Limbah Kulit Udang. Majalah 
BIAM, 12(1), 32-39.

Heidari, F., Razavi, M., Bahrololoom, M. E., Tahriri, M., Rasoulianboroujeni, M., Koturi, H., \& Tayebi, L. (2018). Preparation of natural chitosan from shrimp shell with different deacetylation degree. Materials Research Innovations, 22(3), 177-181. https://doi.org/10.1080/14328917.2016.1271591

Imtihani, H. N., Permatasari, S. N., \& Thalib, F. A. (2021). Solid Dispersion Characteristics of Whiteleg Shrimp ( Litopenaeus vannamei) Extracted Chitosan with HPMC and PVP K-30 as Anticholesterol Agents. 14(July), 3560-3566. https://doi.org/10.52711/0974-360X.2021.00616

Kenny, A. P. (1952). The determination of cholesterol by the Liebermann-Burchard reaction. The Biochemical journal, 52(4), 611-619. https://doi.org/10.1042/bj0520611

Lindawati, N. Y., \& Ningsih, D. W. (2020). Aktivitas Antikolesterol Ekstrak Etanol Buah Kiwi Hijau (Actinidia deliciosa). Jurnal Ilmiah Manuntung, 6(2), 183. https://doi.org/10.51352/jim.v6i2.344

Maidin, A. N., Natsir, H., \& Dali, S. (2017). Enzimatic production of chitosan from waste of rajungan crab shell and it's aplication in cholesterol reduction by in vitro test. Indonesia Chimica Acta, $10(1), 25-34$.

Maidin Nasir Alfian. (2017). Produksi Kitosan Dari Limbah Cangkang Kepiting Rajungan (Portunidae) Secara Enzimatis Dan Aplikasinya Sebagai Penurun Kolesterol. In Universitas Hasanuddin Makassar (Vol. 01).

Miller, J. N. (James N. ., Miller, J. C. (Jane C., \& Miller, J. C. (Jane C. (2000). Statistics and chemometrics for analytical chemistry. 271.

Nasional, B. S. (2013). Kitosan Syarat Mutu dan Pengolahan SNI 7949 BSN.

Pagala, M. A. (2011). Pengaruh Pemberian Kitosan Terhadap Kualitas Sel Darah Itik Petelur. 21, 116120.

Pratiwi, R. (2014). Manfaat Kitin dan Kitosan bagi Kehidupan Manusia. Oseana, XXXIX(1), 35-43.

Puspitasari, M. (2014). Efek Iradiasi Gamma Terhadap Aktivitas Anti Inflamasi Kitosan Secara in Vitro (Nomor September). UIN Syarif Hidayatullah Jakarta.

Rasio, P., Kitin, M., Dan, N., Kitosan, K., Disintesis, Y., Limbah, D., Udang, I., \& Kerja, C. (2017). Pengaruh Rasio Massa Kitin/NaOH dan Waktu Reaksi Terhadap Karakteristik Kitosan Yang Disintesis Dari Limbah Industri Udang Kering. Universitas Riau, 1, 61-67.

SNI 01-2891-1992. (n.d.). Kadar Air Metode Oven dan Kadar Abu. Diambil 2 September 2021, dari https://adoc.pub/a-kadar-air-sni-metode-oven-b-kadar-abu-sni-abu-total.html

Taufan, S., Radhitya, M., \& Zulfahmi. (2010). Pemanfaatan Limbah Kulit Udang sebagai Bahan Anti Rayap (Bio-termitisida) pada Bangunan Berbahan Kayu. Universitas Diponegoro.

Trianggani, D. F., \& Sulistiyaningsih. (2018). Dispersi padat. Farmaka, 16(1), 93-102.

Umar, S., Sari, N. V., \& Azhar, R. (2014). Studi Kestabilan Fisika Dan Kimia Dispersi Padat 
Ketoprofen-Polivinil Pirolidon K-30. Jurnal Farmasi Higea, 6(1), 3.

Yanti, R., Drastinawati, \& Yusminar. (2018). Sintesis Kitosan Dari Limbah Cangkang Kepiting Dengan Variasi Suhu Dan Waktu Pada Proses Deasetilasi. Jom FTEKNIK, 5(2), 1-7.

Ylitalo, R., Lehtinen, S., Wuolijoki, E., Ylitalo, P., \& Lehtimäki, T. (2002). Cholesterol-lowering properties and safety of chitosan. Arzneimittel-Forschung/Drug Research, 52(1), 1-7. https://doi.org/10.1055/s-0031-1299848

Zahiruddin, W., Ariesta, A., \& Salamah, E. (2008). Karakteristik Mutu Dan Kelarutan Kitosan Dari Ampas Silase Kepala Udang Windu (Penaeus monodon). Buletin Teknologi Hasil Perikanan, 2, $141-151$. 